23 Skapinakis P, Lewis G, Araya R, Jones K, Williams G. Mental health inequalities in Wales, UK: multi-level investigation of the effect of area deprivation. Br J Psychiatry 2005; 186: 417-22.

24 Hawton K, Harriss L, Hodder K, Simkin S, Gunnell D. The influence of the economic and social environment on deliberate self-harm and suicide: an ecological and person-based study. Psychol Med 2001; 31: 827-36.

25 Johnston A, Cooper J, Webb R, Kapur N. Individual- and area-level predictors of self-harm repetition. Br J Psychiatry 2006; 189: 416-21.

26 Qin $\mathrm{P}$, Agerbo $E$, Bo Mortensen P. Suicide risk in relation to socioeconomic, demographic, psychiatric, and familial factors: a national register-based study of all suicides in Denmark, 1981-1997. Am J Psychiatry 2003; 160: 765-72.

27 Agerbo E, Sterne J, Gunnell D. Combining individual and ecological data to determine compositional and contextual socio-economic risk factors for suicide. Soc Sci Med 2007; 64: 451-61.

28 Martikainen P, Mäki N, Blomgren J. The effects of area and individual social characteristics on suicide risk: a multilevel study of relative contribution and effect modification. Eur J Popul 2004; 20: 323-50.

29 Lewis G, Sloggett A. Suicide, deprivation, and unemployment: record linkage study. BMJ 1998; 317: 1283-6.

30 Weich S, Lewis G. Poverty, unemployment, and common mental disorders: population based cohort study. BMJ 1998; 317: 115-19.
31 Kunce $M$, Anderson $A$. The impact of socioeconomic factors on state suicide rates: a methodological note. Urban Stud 2002; 39: 155-62.

32 Durkheim E. Suicide: A Study in Sociology (transl. Spalding J, Simpson G). Routledge \& Kegan Paul, 1952.

33 Congdon P. Commentary: contextual effects: index construction and technique. Int J Epidemiol 2004; 33: 741-2.

34 Northern Ireland Statistics and Research Agency. Northern Ireland 2001 Output. http://www.nisra.gov.uk/census/census2001output/index.htm.

35 Office for National Statistics. Census 2001. http://www.statistics.gov.uk/ census2001/census2001.asp.

36 Stringer P. Health Inequalities, Religious Affiliation and Urban-rural Status: $A$ Report to the Department of Health and Social Services (NI). Northern Ireland DHSS, 1992.

37 Townsend $\mathrm{P}$, Philimore $\mathrm{P}$, Beattie A. Health and Inequalities in the North. Croom Helm, 1988

38 Carstairs V , Morris R. Deprivation and Health in Scotland. Aberdeen University Press, 1991.

39 O'Reilly G, O'Reilly D, Rosato M, Connolly S. Urban and rural variations in morbidity and mortality in Northern Ireland. BMC Public Health 2007; 7: 123 (http://www.biomedcentral.com/1471-2458/7/123).

\title{
Word pictures of depression: tearfulness
} Sharon Mcconville

Shortly after my admission to hospital, I wrote:

'Today, tears came. They poured out of me, not like little wavelets brimming over the edge of an overfilled swimming pool, but in a great gush, as if the reservoir of emotion and despair which is my soul had swelled to burst its dams. Deep, guttural sobs racked my body. I was in the foyer of the cancer centre when it happened. It was the sight of [ . . . ] walking towards me with open arms, ready to enfold me in a warm embrace, which precipitated the flow. As I buried my head in her soft coat collar, her lips kissed my hair. She supported me as we walked towards two adjacent chairs, where we sat down, wrapped in one another's arms, me crying uncontrollably; she stroking my head. I was aware of seemingly hundreds of pairs of eyes fixed upon me. In a sense, it was heartening to know that such a sight is not uncommon in the cancer centre. I have seen many people crying there before myself. However as people around me whispered; "That poor girl. She must have lost somebody," or "She must be ill. Look how thin she is. Maybe she's had bad news," I felt a pang of guilt. After all, I was only depressed. Then I realised - dare I say it - that I honestly believed that a death or diagnosis of cancer would actually have been easier to deal with.

I continued to cry all afternoon. I cried in the nurses' station, surrounded by staff, including a rather bemused-looking dietitian who had come to see me and whom I later realised had actually been at school with me, albeit a couple of years ahead. I cried in the interview room, as I waited to speak to this dietitian, who ultimately decided to defer the discussion until a later date. I cried in the dormitory, where I desperately tried to collect myself by sipping at a cup of herbal tea which one of the nurses had prepared for me. I cried in the day room as soon as [ . . . ] appeared to visit me. I cried in the office belonging to [my lead nurse] when he decided that we needed to have a chat later in the afternoon. I cried in my bed. I cried in the corridor. I cried in the toilet. I finished up exhausted and suffering from frightening palpitations. My eyes were burning, the lids rasping against them like sandpaper, and my head was pounding. At the same time, I felt some measure of relief: a relief akin to that experienced by a gentleman with prostatism whose bladder has just been catheterised, or that felt when a swollen, engorged boil is lanced and the pus can drain freely from it.

Aside from relief, however, I felt something else. It was as if something momentous had happened to me. I felt as I had been suddenly stripped, my vulnerability laid bare. I imagined myself as one of those plasticated bodies in the anatomy exhibition which has recently caused such controversy in the media, my skin peeled back to expose my raw flesh and sinews. It was a scary, dizzying sort of a feeling. I was unsure quite what it meant.' 